\title{
Government Policy in the Development of Electric Motor Vehicle Technology for an Environmental Friendly Transportation
}

\author{
Andina Elok Puri Maharani ${ }^{1, *}$ Alvinia Khotimatul Husna Sutopo ${ }^{2}$ \\ ${ }^{1}$ Faculty of Law, Sebelas Maret University, Central Java, Indonesia \\ ${ }^{2}$ Faculty of Law, Sebelas Maret University, Central Java, Indonesia \\ *Corresponding author. Email: andinaelok@staff.uns.ac.id
}

\begin{abstract}
This paper examines government policies in the development of electric motor vehicle technology to realize environmentally friendly transportation. Electric vehicles based on new technology that can reduce carbon emissions. It is considered to support the contribution to the increase of greenhouse gases in the atmosphere. A number of countries have also committed to gradually eliminating the use of conventional fossil-fueled vehicles to then rely entirely on the use of electric vehicles. The purpose of this paper is first toexamine policy support from the Government of Indonesia in developing electric motorized vehicles to realize environmentally friendly transportation. Second, to examine the supporting and inhibiting factors for the development of electric vehicles in Indonesia. This writing uses the literature study method. The results of the analysis show that the Government of Indonesia has issued Presidential Regulation Number 55 of 2019 concerning the Acceleration of the Battery-based Electric Motor Vehicle Program for road transportation, this shows a commitment to realizing environmentally friendly transportation. The supporting factor for this policy is that electric motorized vehicles have more efficient power, but there are inhibiting factors, namely the support for infrastructure that has not been maximized.
\end{abstract}

Keywords: Policy, Technology, Electric Motorized Vehicles (KBL), Environmentally Friendly.

\section{INTRODUCTION}

\subsection{Background}

At this time, the air on earth is increasingly polluted by pollution caused by exhaust fumes from factories. The biggest contribution to air pollution today is from exhaust gases from vehicles. In Indonesia, there are thousands of vehicles that still use non-environmentally friendly fuels, this is a major player in contributing to the largest air pollution that can cause global warming.[1] And the most widely used energy source in the world is fossil energy in the form of fuel oil. Indonesia is still very dependent on fossil energy. Almost 95\% of Indonesia's energy needs are still supplied by fossil energy. Fossil energy is nonrenewable energy and will run out in the next few years. It is predicted that in no more than 50 years, the world's fossil energy will run out.[2] Apart from being exhausted, fossil energy also has a negative impact on the environment. Most of the main energy consumed by the Indonesian people also comes from fossil energy. Fossil energy is often called BBM (fuel oil). The sustainable use of fossil fuels has led to a steady increase from the concentration of $\mathrm{CO} 2$ in the atmosphere to $400.26 \mathrm{ppm}$ in 2015. The transportation sector is a major contributor to the world's fossil fuel consumption and greenhouse gas emissions. In addition, $\mathrm{CO} 2$ emissions produced by the transportation sector are $22.9 \%$ of the total $\mathrm{CO} 2$ emissions in the world.[3] So in order to slow down climate change and develop sustainable energy resources, the world community must support a major energy transition from fossil fuels to renewable energy and the use of alternative energy sources. For developing countries such as Indonesia, Electric Motorized Vehicle technology, which is then called KBL is a "disruptive technology" whose presence has been awaited to help 
reduce the use of diesel fuel, especially in the transportation sector. [4] Based on this urgency, the state needs to be present in the context of its policy and implementation to develop KBL technology to realize environmentally friendly transportation.

\subsection{Problem Formulation}

Based on the above background, several problem formulations can be drawn, namely:

1. How is the policy support from the Government of Indonesia in developing electric motorized vehicles (KBL) to realize environmentally friendly transportation?

2. What are the supporting and inhibiting factors for the policy of developing electric motorized vehicles $(\mathrm{KBL})$ ?

\section{RESEARCH METHOD}

In this paper, a literature review research method is used which is sourced from various studies that have been conducted previously, such as books, journals, and other literature. After the data is collected, the writer uses data analysis techniques to analyze the data so that a conclusion can be drawn.

\section{DISCUSSION RESULTS}

\subsection{Policy from the Government of Indonesia in Developing Electric Motorized Vehicles to Realize Environmentally Friendly Transportation}

Currently, electric-based vehicles are not something that is considered foreign because it has often been discussed in the community. The use of KBL is also expected to contribute to reducing carbon emissions from the transportation sector. A number of countries have also committed to gradually eliminating the use of conventional fossil-fueled vehicles and then relying on the use of KBL. In the Indonesian context, since a few years ago, electric cars were introduced by several vehicle manufacturers to the Indonesian market. Car manufacturers from Germany, Japan and Korea have introduced some of their electric car products to consumers in Indonesia. In the Indonesian market today, there are at least three types of electric cars. The three types are electric cars withplug-in hybrid electric vehicle (PHEV), hybrid electric vehicle (HEV) and battery electric vehicle (BEV) technology. Meanwhile, the United States electric car manufacturer, Tesla, is widely rumored to be building a factory in Batang, Central Java. [5] In Indonesia itself, the growth of KBL in Indonesia continues to increase, with an average percentage of $11.5 \%$ per year for the last 10 years (KESDM, 2017). The use of fuel oil for motor vehicles also increased by $5 \%$ a year, mostly using imported fuel. Both of these have contributed to the decline in the air quality index, where on average, major cities in Indonesia have an "unhealthy" air quality level. [6] Therefore, the Government is very serious in encouraging the development of the electric vehicle technology industry. One way is by providing incentives to the industry in order to accelerate the KBL or battery-based program. This is stated in Presidential Regulation Number 55 of 2019 concerning the Acceleration of the Battery-Based Electric Motor Vehicle Program for Road Transportation. As a form of full support for the existence of electric vehicles, the Indonesian government also plans to replace fossil fuel vehicles with electric vehicles. The government is targeting, from 2021 to 2024, the replacement of fossilfueled official vehicles can be realized throughout Indonesia. Several policies have also been prepared, such as zero percent transfer fees for electric vehicles, and zero percent down payment for electric vehicles, as well as exemption from PPnBM (sales tax on luxury goods) for plug-in hybrid electric vehicles and battery electric vehicles. [5]

With the issuance of Presidential Regulation Number 55 of 2019 concerning the Acceleration of the BatteryBased Electric Motor Vehicle Program for Road Transportation, the government is committed to developing a transportation energy system that leads to an electric-based vehicle (KBL) policy. Underlying the government's commitment to shifting conventional vehicles to $\mathrm{KBL}$ is the new technology for transportation energy to anticipate the projected growing demand for fuel oil. The main impact of the mass transition of road transportation to electric cars is the increase in the need for electrical energy on a large scale. However, in accelerating the KBL program, support from all parties is needed in order to reduce the inhibiting factors that are considered by consumers' preferences in choosing KBL, namely price, maintenance, vehicle durability and infrastructure readiness. Through the supervisory function, the DPR can also play a role in ensuring the acceleration of the conversion of conventional vehicles to KBL runs well and ensuring that the performance of the government and its supporting infrastructure is at the right stage. Several regions have also followed up on Presidential Regulation No. 55 of 2019, such as Jakarta. DKI Jakarta Governor Regulation Number 3 of 2020 concerning the Tax Incentive for Transferring Motor Vehicles (BBN-KB) on Battery-Based Electric Motorized Vehicles is expected to stimulate the population of electric vehicles in the capital city.

As stated in Chapter II Article paragraph 2, all battery-based electric vehicles will not be subject to a biofuel tax. Especially for those who have electric cars, it is also certain that they will be free from the odd-even policy in Jakarta. It is hoped that other regions will also have policy and infrastructure readiness for the development of this technology.[7] 


\subsection{The Supporting and Inhibiting Factors of the Policy for the Development of Electric Motorized Vehicles}

\subsubsection{The supporting factors}

The Government's policy is supported by the advantages of electric motorized vehicles whose demand is also increasing. In the context of users, electric vehicles have several advantages, namely:

- The operational costs that come out do not continue to flow because the user does not buy fuel oil but pays the cost of electric power for charging the battery.

- Maintenance Easier, due to the use of electricpowered machines, users do not need to warm up/cool the machine.

- More responsive for increasing speed because the electric motor in electric vehicles is more responsive when the user increases speed, especially when traveling long distances.

- Reduces noise pollution, as electric vehicles produce a minimum of noise.

- Environmentally friendly because users can contribute to reducing greenhouse gas emissions and the impact of climate change. [6]

\subsubsection{Inhibiting Factors}

Government policies also have weaknesses, one of which is the nature of the technology itself and infrastructure

- KBL using batteries, even though it is fuel efficient, but operational costs can be expensive due to three things: the battery (battery charging time is still long, it can take between 4-6 hours to full with a mileage of $160 \mathrm{~km}$, although there are also electric cars that have a battery capacity of $38.3 \mathrm{kWh}$ and can be recharged up to $80 \%$ in just 57 minutes, called fast-charging $(50-\mathrm{kW})$ with mileage $373 \mathrm{~km})$, home electric power, and electric car vehicle tax.

- In terms of infrastructure, namely the completeness of infrastructure, the lack of public refueling places for electric cars is not balanced with the demand for electricity which is quite large and not all cities provide this facility.[7]

\section{CLOSING}

\subsection{Conclusions}

1) The Government's policy to support electric motorized vehicle technology to realize environmentally friendly transportation is stated in
Presidential Regulation Number 55 of 2019 concerning the Acceleration of the Battery-Based Electric Motor Vehicle Program for Road Transportation.

2) The policy supporting factor is the nature of the KBL technology that does not use fossil fuels so that it is considered cheaper and environmentally friendly so that the public is interested. However, there is an inhibiting factor, namely the support of infrastructure or infrastructure that is not ready, such as charging stations that are not widely available. Further research is needed on this matter, because the development of the electric vehicle industry in Indonesia is currently still relatively difficult to do with electric vehicle technology, due to the high cost of developing electric vehicles, especially in producing electric vehicle batteries. Indonesia also does not have a power plant infrastructure that can support it if applied nationally because there will be a spike in electricity demand nationally.

\subsection{Suggestions}

Commitment to an environmentally friendly country can be seen from his attention to environmentally friendly transportation. The President has issued presidential regulations, but in the legal system, this policy support must be supported by adequate infrastructure

\section{AUTHORS' CONTRIBUTION}

At the writing of this article, all the authors compiled and also designed this article. All authors conducted data analysis and revised the article manuscript so that a writing of this article was formed.

\section{ACKNOWLEDGMENTS}

The authors would like to express their deepest gratitude to the Faculty of Law, Sebelas Maret University, which has provided support and to the authors of the journals we use for providing useful knowledge for the sustainability of our article writing.

\section{REFERENCES}

[1] A. Budiarto, O. Judianto, U. E. Unggul, J. Arjuna, and U. Kebon, "Perancangan Mobil Listrik Ramah Lingkungan."

[2] M. A. Rahman, "Pembuatan mobil listrik untuk solusi transportasi ramah lingkungan (mobil baskara)," J. Ris. Drh., vol. XII, no. 2, pp. 1819 1837, 2013. 
[3] V. Tulus Pangapoi Sidabutar, "Kajian pengembangan kendaraan listrik di Indonesia: prospek dan hambatannya," J. Paradig. Ekon., vol. 15, no. 1, pp. 21-38, 2020, doi: 10.22437/paradigma.v15i1.9217.

[4] M. D. N. Dawami, H. Heryanto, and A. W. Dani, "Kajian Tentang Uji Jalan Kendaraan Listrik Dengan Studi Kasus Perjalanan Bandung Jakarta," J. Teknol. Elektro, vol. 11, no. 2, p. 64, 2020, doi: 10.22441/jte.2020.v11i2.001.

[5] R. Wulandari, "Mobil Listrik Transportasi Masa Depan Apakah Ada Dampak Bagi Lingkungan," Mongabay Situs Berita Lingkungan, 2020. https://www.mongabay.co.id/2020/11/22/mobillistrik-transportasi-masa-depan-apakah-adadampak-bagi-lingkungan/

[6] P. Sindhu, "The future of transport networks," Opt. Fiber Commun. Conf. OFC 2015, 2015, doi: 10.1364/ofc.2015.tu1a.1.

[7] M. Aziz, Y. Marcellino, I. A. Rizki, S. A. Ikhwanuddin, and J. W. Simatupang, "Studi Analisis Perkembangan Teknologi Dan Dukungan Pemerintah Indonesia Terkait Mobil Listrik," TESLA J. Tek. Elektro, vol. 22, no. 1, p. 45, 2020, doi: 10.24912/tesla.v22i1.7898. 